\title{
Hubungan kekambuhan pada pasien skizofrenia dengan pengetahuan dan sikap keluarga dalam merawat pasien
}

\author{
Slamet Rahayu ${ }^{1}$, Teguh Pribadi ${ }^{*}$, Yansuri ${ }^{3}$ \\ 1 UPTD Puskesmas Batanghari Kabupaten Lampung Timur \\ 2Program Studi IImu Keperawatan Universitas Malahayati \\ ${ }^{3}$ Rumah Sakit Jiwa Daerah Provinsi Lampung \\ Korespondensi Penulis: Teguh Pribadi. *Email: teguh@malahayati.ac.id
}

\section{Abstract \\ Knowledge, attitudes and practices of caregivers for the prevention of relapse in patients with schizophrenia}

Background: Patients with schizophrenia often experience a relapse after completing their treatment in a mental hospital. To overcome the problem, the psychosocial management needs support from caregivers. The caregivers are a very important factor in the healing process. Caregivers attitude is beneficial for the development of a healthy personality without distractions. Factors that affect the relapse of the Client such as doctor, the client, caregivers, environment. Patients who received social skills training, antipsychotic drugs and psychoeducation reported rarely to relapse.

Purpose: To analyze in knowledge, attitudes, and practices of caregivers to prevent relapse in patients with schizophrenia.

Method: A quantitative research with a cross-sectional approach. The population in this study were all caregivers, amounting to 41 respondents, while the sampling technique was taken using the total population method. The analysis used univariate and bivariate using the chi-square test.

Results: The study showed that $15(36.6 \%)$ respondents who had an expert knowledge, the patient rarely experienced relapse, while respondents who had a poor knowledge, the number of patient that often experienced relapse was $9(22.0 \%)$ and $p=0,003$ OR 12.500, in the study showed that $14(34.1 \%)$ respondent had a supportive attitude, the patient would be rarely relapse. And caregivers could prevent, the number of patient that often experienced relapse was $17(41.5 \%)$ and $p=0.002$, OR 11.333 .

Conclusion: There is a relationship in knowledge, attitudes, and practices of caregivers to prevent relapse in patients with schizophrenia at Batanghari East Lampung, Indonesia.

\section{Keywords: Knowledge; Attitudes; Practices; Caregivers; Prevent relapse; Patients; Schizophrenia}

Pendahuluan: Penderita Skizofrenia seringkali mengalami kambuh setelah selesai menjalani masa perawatan di rumah sakit jiwa. Untuk mengatasi masalah gangguan jiwa skizofrenia, butuh dukungan penanganan psikososial yang berasal dari keluarga. Keluarga merupakan faktor yang sangat penting dalam proses kesembuhan klien dimana sikap keluarga bermanfaat untuk perkembangan menuju kepribadian yang sehat tanpa gangguan. Faktor yang mempengaruhi kekambuhan Klien seperti dokter yang merawat, klien, keluarga, dan lingkungan sekitar. Penderita yang mendapat latihan keterampilan sosial, obat antipsikotik dan psikoedukasi dilaporkan jarang mengalami kekambuhan

Tujuan: Untuk mengetahui hubungan pengetahuan dan sikap keluarga tentang perawatan pasien skizofrenia di rumah dengan kekambuhan.

Metode: Penelitian kuantitatif dengan pendekatan cross sectional. Populasi dalam penelitian ini adalah semua keluarga pasien skizofrenia yaitu berjumlah 41 responden, di UPTD Pukesmas Batanghari Kabupaten Lampung Timur. sedangkang teknik sampling yang diambil dengan menggunakan metode total populasi. Analisis yang digunakan univariat dan bivariat menggunakan uji chi-square.

Hasil: Menunjukkan bahwa $15(36.6 \%)$ responden yang memiliki pengetahuan kategori baik, dan pasien jarang mengalami kekambuhan, sedangkan responden yang memiliki pengetahuan buruk, jumlah pasien yang sering mengalami kekambuhan sebesar $9(22.0 \%)$ dan $p=0,003$ OR 12,500, pada penelitian menunjukkan bahwa 14 $(34.1 \%)$ responden memiliki sikap mendukung, pasien jarang mengalami kekambuhan. Adapun responden yang 
Hubungan kekambuhan pada pasien skizofrenia dengan pengetahuan dan sikap keluarga dalam merawat pasien

tidak mendukung, jumlah pasien yang sering mengalami kekambuhan sebesar $17(41.5 \%)$ dan $p=0,002$, OR 11,333 .

Simpulan: Adanya hubungan antara pengetahuan keluarga tentang perawatan pasien di rumah dengan kekambuhan pasien dan juga adanya hubungan antara Sikap Keluarga terkait perawatan pasien jiwa di rumah dengan kekambuhan di UPTD Pukesmas Batanghari Kabupaten Lampung Timur.

\section{Kata Kunci: Kekambuhan; Pasien; Skizofrenia; Pengetahuan; Sikap; Keluarga; Merawat}

\section{PENDAHULUAN}

Kesehatan jiwa masih menjadi salah satu permasalahan kesehatan yang signifikan di dunia. Terdapat sekitar 35 juta orang terkena depresi, 60 juta orang terkena bipolar, 21 juta terkena skizofrenia, serta 47,5 juta terkena dimensia (World Health Organization, 2013; Wiharjo, 2014).

Gangguan jiwa dapat terjadi pada siapa saja dan kapan saja. Hasil analisis sekitar 450 juta orang menderita gangguan jiwa termasuk skizofrenia. Skizofrenia menjadi gangguan jiwa paling dominan dibanding gangguan jiwa lainnya. Penderita gangguan jiwa sepertiga tinggal di negara berkembang, 8 dari 10 orang yang menderita skizofrenia tidak mendapatkan penanganan medis. Gejala skizofrenia muncul pada usia 15-25 tahun lebih banyak ditemukan pada laki-laki dibandingkan pada perempuan (Ashturkar \& Dixit, 2013).

Skizofrenia adalah salah satu jenis psikotik yang menunjukan gelaja halusinasi dan waham (Townsend, 2011). Pasien dengan skizofrenia mempunyai gejala salah satunya adalah halusinasi akibat cemas 2 berkepanjangan yang tidak mampu dihadapi pasien menggunakan mekanisme koping dalam diri pasien. Pendapat lain menyebutkan bahwa halusinasi yang terjadi pada pasien skizofrenia halusinasi gangguan alam perasaan yang tidak menentu, isi kebesaran atau kejaran, sering bertengkar atau berdebat, dan perilaku cemas yang tidak menentu dan kemarahan (Hawari, 2014). Prevalensi ganggunan mental emosional yang ditunjukkan dengan gejala-gejala depresi dan kecemasan untuk usia 15 tahun ke atas mencapai sekitar 14 juta orang atau $6 \%$ dari jumlah penduduk Indonesia. Sedangkan prevalensi gangguan jiwa berat, seperti skizofrenia mencapai sekitar 400.000 orang atau sebanyak 1,7 per 1.000 penduduk (Kementerian Kesehatan Republik Indonesia, 2013).
Kekambuhan merupakan keadaan klien dimana muncul gejala yang sama seperti sebelumnya dan mengakibatkan klien harus dirawat kembali (Andri, 2008). Periode kekambuhan adalah lamanya waktu tertentu atau masa dimana klien muncul lagi gejala yang sama seperti sebelumnya dan mengakibatkan klien harus dirawat kembali. Kekambuhan gangguan jiwa psikotik adalah munculnya kembali gejala-gejala pisikotik yang nyata. Angka kekambuhan secara positif hubungan dengan beberapa kali masuk Rumah Sakit (RS), lamanya dan perjalanan penyakit. Penderitapenderita yang kambuh biasanya sebelum keluar dari RS mempunyai karakteristik hiperaktif, tidak mau minum obat dan memiliki sedikit keterampilan sosial (Akbar, 2008). Penderita Skizofrenia mengalami rawat ulang setelah follow up selama 1 tahun sebanyak $49 \%$, sedangkan penderitapenderita non-Skizofrenia hanya $28 \%$. Dalam waktu 6 bulan pasca rawat didapatkan 30\%-40\% penderita mengalami kekambuhan, sedangkan setelah 1 tahun pasca rawat $40 \%-50 \%$ penderita mengalami kekambuhan, dari setelah 3-5 tahun pasca rawat didapatkan 65\%-75\% penderita mengalami kekambuhan. Penderita dengan skizofrenia dapat mengalami remisi dan kekambuhan, mereka dapat dalam waktu yang lama tidak muncul gejala, maka skizofrenia sering disebut dengan penyakit kronik, karena itu perlu mendapatkan perhatian medis yang sama, seperti juga individu-individu yang menderita penyakit kronik lainnya seperti hipertensi dan diabetes mellitus (Akbar, 2008).

Prevalensi gangguan jiwa berat di Provinsi Lampung menurut Hasil Riskesdas 2013 sebesar 0,8 permil. Berdasarkan hasil tersebut dengan jumlah penduduk Provinsi Lampung 7.767.312 maka diperkirakan 6.213 penduduk di Provinsi Lampung mengalami gangguan jiwat berat dan

\section{Slamet Rahayu', Teguh Pribadi ${ }^{2 *}$, Yansuri $^{3}$}

'UPTD Puskesmas Batanghari Kabupaten Lampung Timur ${ }^{2}$ Program Studi llmu Keperawatan Universitas Malahayati

${ }^{3}$ Rumah Sakit jiwa Daerah Provinsi Lampung

Korespondensi Penulis: Teguh Pribadi. *Email: teguh@malahayati.ac.id 
Hubungan kekambuhan pada pasien skizofrenia dengan pengetahuan dan sikap keluarga dalam merawat pasien

sekitar 14,3\% (888) orang pernah dilakukan pemasungan. Jumlah kasus pasung yang sudah pernah ditangani baik oleh Rumah Sakit Jiwa Daerah maupun Dinas Kesehatan Provinsi Lampung selama tahun 2013 sebanyak 66 orang dengan jumlah terbanyak di Kabupaten Lampung Timur sebanyak 29 kasus (Kementerian Kesehatan Republik Indonesia, 2013; Tabrani, 2014).

Jumlah kunjungan rawat jalan pada Puskesmas di Lampung Timur pasien jiwa sebanyak 2.597 jiwa. Proporsi jenis gangguan jiwa skizofren $46 \%$, ganguan depresi $19 \%$, retardasi mental $11 \%$, epilepsi $6 \%$, psikotik akut $5 \%$, ganguan mental organik $5 \%$, ganguan jiwa anak dan remaja $5 \%$, ganguan neurotik $3 \%$. Kecamatan Batanghari merupakan jumlah tertinggi sebaran penderita gangguan jiwa dan pasung di Kabupaten Lampung Timur dengan jumlah proporsi gangguan jiwa skizofren sebanyak 61\% (Dinas Kesehatan Kabupaten Lampung Timur, 2016).

Angka kejadian skizofrenia yang mengalami kekambuhan di unit rawat jalan Puskesmas Batanghari menjadi jumlah kasus terbanyak dengan jumlah rata-rata 41 pasien pada satu tahun terakhir tahun 2018, data pasien relaps atau kambuh adalah 23 pasien selama satu tahun terakhir.

Tindakan keluarga dalam menangani pasien gangguan jiwa ini diakibatkan oleh kurangnya pengetahuan keluarga mengenai gangguan jiwa. Jika pengetahuan yang dimiliki lebih baik, maka penanganan dilakukan secara medis. Pengetahuan yang dimiliki keluarga mengenai penyakit gangguan jiwa dapat berasal dari berbagai sumber. Selain dari latar belakang pendidikan secara formal, informasi lain dapat berasal dari koran, televisi, majalah kesehatan, ataupun responden mendapat informasi kesehatan dari tenaga kesehatan, yang pada akhirnya akan mempengaruhi pengetahuan responden tentang gangguan jiwa. Selanjutnya sikap keluarga cenderung memperlakukan pasien gangguan kejiwaan dengan disembunyikan, diisolasi, dikucilkan bahkan sampai ada yang dipasung. Hal berbeda jika keluarga bersikap mendukung dengan melakukan pengobatan ke rumah sakit jiwa. Hal ini sangat membantu kesembuhan klien dan

\section{Slamet Rahayu', Teguh Pribadi ${ }^{2 *}$, Yansuri ${ }^{3}$}

'UPTD Puskesmas Batanghari Kabupaten Lampung Timur ${ }^{2}$ Program Studi llmu Keperawatan Universitas Malahayati ${ }^{3}$ Rumah Sakit jiwa Daerah Provinsi Lampung

Korespondensi Penulis: Teguh Pribadi. *Email: teguh@malahayati.ac.id menghambat kekambuhan (Kusumaningtyas, \& Widodo, 2017).

Hasil presurvei yang peneliti lakukan pada tanggal 22 Desember 2018 di Puskesmas Batanghari Kabupaten Lampung Timur terhadap 10 keluarga pasien gangguan jiwa skizofrenia saat melakukan kontrol ulang didapatkan data pengetahuan dan sikap keluarga, bahwa 5 orang $(50 \%)$ dari 10 pasien pernah mengalami kekambuhan (dirawat di rumah sakit jiwa), terdapat 7 orang $(70 \%)$ keluarga tidak mengetahui bahwa pasien skizofrenia memerlukan dukungan emosional (seperti: tidak boleh ikut marah ketika pasien marah, memotivasi pasien melakukan tindakan positif), terdapat 6 orang (60\%) keluarga tidak mengetahui bahwa pasien skizofrenia memerlukan penghargaan dan informasi (seperti: memberikan pujian bila pasien melakukan tugas dengan baik, menyampaikan informasi yang didapatkan dari dokter kepasien langsung), terdapat 5 orang $(50 \%)$ keluarga tidak mengetahui bahwa pasien skizofrenia memerlukan dukungan instrumental (seperti: dibantu dan diantar ke Pelayanan Kesehatan tepat waktu sesuai petunjuk, membantu dalam mencukupi biaya pengobatan).

Data sikap keluarga terhadap pasien skizofrenia di dapatkan bahwa $8(80 \%)$ dari 10 keluarga mengatakan tidak tahu akan cara merawat keluarga dengan gangguan jiwa (sikap menerima), 6 (60\%) dari 10 keluarga bersikap negatif terhadap keluarga ganguan jiwa dengan tidak mengatarkan kontrol ulang dikarenakan sibuk (sikap bertanggung jawab), 8 (80\%) dari 10 keluarga belum bisa mengunakan fasilitas kesehatan dengan baik yaitu dengan harus mematuhi anjuran yang disarankan oleh dokter untuk kontrol ulang (sikap merespon). Berdasarkan fenomena tesebut diatas maka peneliti tertarik melakukan penelitian dengan judul: Hubungan kekambuhan pada pasien skizofrenia dengan pengetahuan dan sikap keluarga dalam merawat pasien di UPTD Pukesmas Batanghari Kabupaten Lampung Timur tahun 2019.

\section{METODE}

Penelitian kuantitatif dengan desain atau rancangan penelitian analitik dengan pendekatan Cross Sectional secara retrospektif. Populasinya 
Hubungan kekambuhan pada pasien skizofrenia dengan pengetahuan dan sikap keluarga dalam merawat pasien

adalah keluarga dari seluruh pasien Skizofrenia pada UPTD Puskesmas Batanghari sebanyak 41 orang, sudah lulus kelaikan etik dari Komisi Etik Penelitian Kesehatan Universitas Malahayati dengan nomor surat keterangan kelaikan etik 225/EC/KEP-UNMAL///2018.

Kekambuhan pada pasien skizofrenia dapat dilihat di catatan medik selama 1 tahun terakhir dimana dinyatakan kambuh apabila selama 1 tahun terakhir pasien $\geq 2$ kali dirawat inap kembali di rumah sakit jiwa dikarenakan gejalanya muncul kembali. Katehori Tidak kambuh (dengan catatan medik pernah dirawat $<2$ kali dirawat inap selama 1 tahun terakhir.Instrumen pengetahuan keluarga sebanyak 20 item pertanyaan (Jika nilai skor $<50 \%$ kategori berpengetahuan buruk dan Jika nilai skor $\geq 50 \% \%$ kategori berpengetahuan baik). Instrumen sikap keluarga sebanyak 10 item pertanyaan(Jika nilai skor $<50 \%$ kategori tidak mendukung dan Jika nilai skor $\geq 50 \% \%$ kategori mendukung).

Kuesioner yang di gunakan sudah melalui uji validitas peneliti sebelumnya, untuk instrumen pengetahuan telah dilakukan uji validitas dan reliabilitas dengan metode korelasi bivariate pearson dengan hasil 0.750 hingga 0.840 dan instrumen sikap dengan hasil validitas 0.725 hingga 0.850 . Kemudian hasil data yang di dapatkan dianalisis di program SPSS dengan menggunakan uji Chi Square.

HASIL

Tabel 1. Karakteristik Demografi Responden N=41

\begin{tabular}{|c|c|c|c|c|}
\hline Demografi & & $\mathrm{n}$ & $\%$ & $M \pm S D$ \\
\hline $\begin{array}{l}\text { Keluarga yang merawat } \\
\text { (Usia/Tahun)(Rentang: } 21-53 \text { ) } \\
\text { *Usia pasien (Tahun)(Rentang: 18-74) }\end{array}$ & & 41 & & $32.32 \pm 8.04$ \\
\hline *Lamanya sakit (Tahun)(Rentang: 2-35) & & 41 & & $13.76 \pm 9.45$ \\
\hline $\begin{array}{l}\text { *Riwayat Kekambuhan dalam setahun } \\
\text { terakhir (Rentang: } 1-4 \text { ) }\end{array}$ & & 41 & & $1.73 \pm 0.77$ \\
\hline Jenis Kelamin & $\begin{array}{l}\text { Laki-laki } \\
\text { Perempuan }\end{array}$ & $\begin{array}{c}34 \\
7\end{array}$ & $\begin{array}{l}82.9 \\
17.1\end{array}$ & \\
\hline Pendidikan & $\begin{array}{l}\text { Tidak Sekolah } \\
\text { Sekolah Dasar (SD) } \\
\text { SMP } \\
\text { SMA } \\
\text { Perguruan Tinggi (PT) }\end{array}$ & $\begin{array}{c}4 \\
15 \\
13 \\
6 \\
3\end{array}$ & $\begin{array}{l}9.835 .6 \\
31.7 \\
14.67 .3\end{array}$ & \\
\hline Pekerjaan & $\begin{array}{l}\text { Bekerja disamping merawat } \\
\text { pasien } \\
\text { Hanya merawat pasien }\end{array}$ & 34 & $\begin{array}{l}73.9 \\
26.1\end{array}$ & \\
\hline Status Perkawinan & $\begin{array}{l}\text { Belum Menikah } \\
\text { Menikah } \\
\text { Janda atau Duda }\end{array}$ & $\begin{array}{c}4 \\
32 \\
5\end{array}$ & $\begin{array}{l}9.8 \\
78.0 \\
12.2\end{array}$ & \\
\hline Pengetahuan Keluarga & $\begin{array}{l}\text { Baik } \\
\text { Buruk }\end{array}$ & $\begin{array}{l}24 \\
17\end{array}$ & $\begin{array}{l}58.5 \\
41.5\end{array}$ & \\
\hline Sikap Keluarga & $\begin{array}{l}\text { Mendukung } \\
\text { Tidak mendukung }\end{array}$ & $\begin{array}{l}21 \\
20\end{array}$ & $\begin{array}{l}51.2 \\
48.8\end{array}$ & \\
\hline
\end{tabular}

Slamet Rahayu', Teguh Pribadi", Yansuri ${ }^{3}$

'UPTD Puskesmas Batanghari Kabupaten Lampung Timur

${ }^{2}$ Program Studi llmu Keperawatan Universitas Malahayati

${ }^{3}$ Rumah Sakit jiwa Daerah Provinsi Lampung

Korespondensi Penulis: Teguh Pribadi. *Email: teguh@malahayati.ac.id 
Hubungan kekambuhan pada pasien skizofrenia dengan pengetahuan dan sikap keluarga dalam merawat pasien

\begin{tabular}{llll}
\hline & & & \\
*Kekambuhan Pasien & Kambuh & 23 & 56.1 \\
& Tidak kambuh & 18 & 43.9 \\
\hline
\end{tabular}

\section{*=Pasien yang dirawat}

Berdasarkan tabel 1. diketahui responden (keluarga yang merawat pasien) sebanyak 41 berusia antara 21 tahun sampai 53 tahun dengan mean sebesar 32.32 dan standar deviasi 8.04. Berjenis kelamin terbanyak lakilaki sebanyak $82,9 \%$, tingkat pendidikan terbanyak sekolah dasar (SD) sebanyak $36,6 \%$, status perkawinan terbanyak menikah sebanyak $78 \%$, riwayat kekambuhan pasien yang dirawat terbanyak adalah riwayat kekambuhan sekali sebanyak $43,9 \%$, dengan mean sebesar 1.73 dan standar deviasi 0.77 . Dilihat dari lamanya pasien sakit dengan mean sebesar 13.76 dan standar deviasi 9.45 .

Dilihat responden yang memiliki pengetahuan baik yaitu 24 (58,5\%), dan yang memiliki Sikap yang mendukung (positif), lebih banyak yaitu $21(51,2 \%)$ responden, sedangkan menurut data catatan medik pasien yang mengalami kekambuhan (kambuh lebih dari 2 kali dalam waktu yang berbeda dalam kurun waktu satu tahun terakhir sebanyak $23(56,1 \%)$

\section{Tabel 2. Hubungan Variabel Dengan Kekambuhan N=41}

\begin{tabular}{|c|c|c|c|c|c|c|c|c|}
\hline \multirow{3}{*}{ Variabel } & \multicolumn{4}{|c|}{ Kekambuhan } & & & \multirow[t]{3}{*}{$p$-value } & \multirow[t]{3}{*}{ OR } \\
\hline & \multicolumn{2}{|c|}{ Kambuh } & \multicolumn{2}{|c|}{ Tidak Kambuh } & \multicolumn{2}{|c|}{ Total } & & \\
\hline & $\mathrm{n}$ & $\%$ & $\mathrm{n}$ & $\%$ & $\mathbf{N}$ & $\%$ & & \\
\hline \multicolumn{9}{|l|}{$\begin{array}{l}\text { Pengetahuan } \\
\text { keluarga }\end{array}$} \\
\hline Baik & 9 & 22.0 & 15 & 36.6 & 24 & 58.5 & 0.003 & $12.500(2.304-67.817)$ \\
\hline Buruk & 15 & 36.6 & 2 & 4.8 & 17 & 41.5 & & \\
\hline \multicolumn{9}{|l|}{ Sikap Keluarga } \\
\hline Mendukung & 7 & 17.0 & 14 & 34.1 & 21 & 51.2 & 0.002 & $11.333(2.463-52.147$ \\
\hline Tidak mendukung & 17 & 41.5 & 3 & 7.3 & 20 & 48.8 & & \\
\hline
\end{tabular}

Hasil penelitian menunjukkan bahwa 15 $(36.6 \%)$ responden yang memiliki pengetahuan yang kurang baik, mengalami kekambuhan, sedangkan responden yang memiliki pengetahuan keluarga yang baik, jumlah yang jarang mengalami kekambuhan sebesar 9 (22.0\%) responden. Berdasarkan hasil uji statistik chy-square diperoleh $p=0,003$ berarti $p<a(0,05)$. Dengan OR 12,500 berarti responden dengan pengetahuan rendah memiliki resiko 12 (dua belas) kali lebih besar kekambuhan pada pasien jiwa dibandingkan dengan responden dengan pengetahuan tinggi. Didapatkan $17(41.5 \%)$ responden yang memiliki sikap tidak mendukung perawatan pasien jiwa dirumah, sering mengalami kekambuhan. Adapun responden yang menunjukan sikap mendukung perawatan pasien jiwa dirumah, jumlah yang mengalami kekambuhan sebesar 7 (17.0\%) responden. Berdasarkan hasil uji statistik chysquare diperoleh $p=0,002$ berarti $p<a(0,05)$, dengan OR 11,333 berarti responden dengan sikap tidak mendukung memiliki resiko 11 (sebelas) kali lebih besar kekambuhan pada pasien jiwa dibandingkan dengan responden dengan sikap mendukung.

\section{PEMBAHASAN \\ Pengetahuan terkait perawatan pasien}

Hasil penelitian terdapat hubungan yang bermakna antara pengetahuan keluarga terhadap

\footnotetext{
Slamet Rahayu', Teguh Pribadi ${ }^{2 *}$, Yansuri ${ }^{3}$

'UPTD Puskesmas Batanghari Kabupaten Lampung Timur ${ }^{2}$ Program Studi llmu Keperawatan Universitas Malahayati

${ }^{3}$ Rumah Sakit Jiwa Daerah Provinsi Lampung

Korespondensi Penulis: Teguh Pribadi. *Email: teguh@malahayati.ac.id
} 
Hubungan kekambuhan pada pasien skizofrenia dengan pengetahuan dan sikap keluarga dalam merawat pasien

kekambuhan pasien gangguan jiwa. Didapatkan nilai significancy $(p)=0,003$ pengetahuan keluarga terhadap kekambuhan pasien gangguan jiwa dan tanda negatif koefesien korelasi menunjukkan ketidaksearahan, artinya semakin tinggi pengetahuan keluarga maka semakin rendah kekambuhan pasien gangguan jiwa, begitupun sebaliknya. Hal ini menunjukkan bahwa pengetahuan masih belum optimal dalam merawat pasien gangguan jiwa karena masih banyak pasien yang sering mengalami kekambuhan yaitu 24 dari 41 pasien.

Hal ini pun didukung oleh hasil penelitian (Akbar, 2008) melaporkan bahwa 49\% penderita Skizofrenia mengalami rawat ulang setelah follow up selama 1 tahun, sedangkan penderita-penderita non-Skizofrenia hanya 28\%. Dalam waktu 6 bulan pasca rawat didapatkan $30 \%-40 \%$ penderita mengalami kekambuhan, sedangkan setelah 1 tahun pasca rawat $40 \%-50 \%$ penderita mengalami kekambuhan, dari setelah 3-5 tahun pasca rawat didapatkan $65 \%-75 \%$ penderita mengalami kekambuhan, Penderita dengan skizofrenia dapat mengalami remisi dan kekambuhan, mereka dapat dalam waktu yang lama tidak muncul gejala, maka skizofrenia sering disebut dengan penyakit kronik, karena itu perlu mendapatkan perhatian medis yang sama, seperti juga individu-individu yang menderita penyakit kronik lainnya seperti hipertensi dan diabetes mellitus. Ada beberapa hal yang bisa memicu kekambuhan skizofrenia, antara lain tidak minum obat dan tidak kontrol ke dokter secara teratur, menghentikan sendiri obat tanpa persetujuan dari dokter, kurangnya dukungan dari keluarga dan masyarakat, serta adanya masalah kehidupan yang berat yang membuat stress (Gusdiansyah, 2018; Elpinar, Indriastuti, \& Susanti, 2019; Direja, 2019).

Ada beberapa faktor yang dapat mempengaruhi pengetahuan seseorang yaitu salah satunya faktor usia (dalam penelitian ini rata rata responden mempunyai umur produkif yaitu usia 18-44 tahun sebanyak 28 responden $(68,3 \%)$ dalam usia tersebut responden masih sangat produktif dan aktif dalam mencari informasi. Menurut analisis peneliti, pengetahuan atau stigma keluarga terhadap penyakit harus dipahami agar bisa mendukung kesembuhan pasien dan bisa meminimalkan kekambuhan. Informasi yang akurat, gejala penyakit, kemungkinan perjalanan penyakit, berbagai bantuan medis dan psikologis dapat meringankan gejala gangguan jiwa yang merupakan informasi yang sangat dibutuhkan keluarga (Rahakbauw, 2018; Anugrah, 2018).

\section{Sikap Keluarga terkait perawatan pasien}

Hasil penelitian terdapat hubungan yang bermakna dan signifikan antara sikap terhadap kekambuhan pasien gangguan jiwa. Didapatkan nilai significancy $(p)=0,002$ sikap keluarga terhadap kekambuhan pasien gangguan jiwa dan tanda negatif koefesien korelasi menunjukkan ketidaksearahan, artinya semakin baik sikap keluarga maka semakin rendah kekambuhan pasien gangguan jiwa begitupun sebaliknya. Responden yang memiliki sikap yang baik, yang jarang mengalami kekambuhan sebanyak 14 $(34.1 \%)$ responden, sedangkan yang sering mengalami kekambuhan hanya $7(17.0 \%)$ responden, ini membuktikan bahwa semakin baik sikap keluarga maka bisa meminimalkan frekuensi kekambuhan. Responden yang memiliki sikap kurang, frekuensi yang sering mengalami kekambuhan sebanyak $17(41.5 \%)$ responden, maka hal ini menunjukkan bahwa semakin tidak baik sikap keluarga maka frekuensi kekambuhan makin meningkat. New Comb adalah seorang ahli psikologi sosial mengatakan bahwa sikap itu merupakan kesiapan atau kesediaan untuk bertindak dan bukan merupakan pelaksanaan motif tertentu (Notoatmodjo, 2012; Hastuti, \& Varlinda, 2017). Sikap belum merupakan suatu tindakan atau aktifitas akan tetapi merupakan predisposisi tindak suatu prilaku, sikap itu masih merupakan reaksi tertutup, bukan merupakan reaksi terbuka atau tingkah laku yang terbuka, sikap merupakan kesiapan untuk bereaksi terhadap objek-objek di lingkungan tertentu sebagai suatu penghayatan terhadap objek.

Tapi penelitian ini tidak senada dengan penelitian yang dilakukan desi suaida yang dilakukan di RSJ. Radjiman Widiodiningrat Lawang dengan judul Pengaruh hubungan peran keluarga dengan kejadian kekambuhan pada pasien skizofrenia. Penelitian ini menyimpulkan Penulis menggunakan tolak ukur usia, jenis kelamin,

\section{Slamet Rahayu', Teguh Pribadi ${ }^{2 *}$, Yansuri ${ }^{3}$}

'UPTD Puskesmas Batanghari Kabupaten Lampung Timur ${ }^{2}$ Program Studi llmu Keperawatan Universitas Malahayati

${ }^{3}$ Rumah Sakit Jiwa Daerah Provinsi Lampung

Korespondensi Penulis: Teguh Pribadi. *Email: teguh@malahayati.ac.id 
Hubungan kekambuhan pada pasien skizofrenia dengan pengetahuan dan sikap keluarga dalam merawat pasien

pendidikan, pekerjaan, hubungan keluarga dengan pasien, tempat tinggal dengan pasien, intensitas pasien masuk rumah sakit, pasien pernah berobat kemedis dan alternatif, peran keluarga, kekambuhan. Sehingga penelitian ini menunjukkan tidak ada hubungan yang signifikan antara peran keluarga dengan kekambuhan pasien skizofrenia. Karena hasil $(p=0,238>0,05) \mathrm{H} 1$ ditolak dan $\mathrm{HO}$ diterima. Kesimpulan: Tidak ada hubungan antara peran keluarga dengan kejadian kekambuhan pada pasien skizofrenia.

Menurut asumsi peneliti, hal ini disebabkan karena faktor yang mempengaruhi kekambuhan meliputi; Klien, Dokter, Penanggung jawab klien, Keluarga, Lingkungan sekitar, Perilaku kepatuhan terhadap program pengobatan. Apabila kita hanya meneliti dari faktor keluarganya saja maka akan dapat menimbulkan hasil yang kurang mendekati dengan teori yang ada, disarankan untuk menambah faktor (variabel) apakah itu dokter atau faktor lingkungan sekitar. Dapat ditambahkan lagi beberapa klien pada saat berada di lingkungan tempat tinggal lebih nyaman dibandingkan ketika berada dalam perawatan dirumah sakit karena harus menjalani beberapa fase-fase pengobatan yang justru dapat menimbulkan stressor yang berlebihan, karena tempat yang terbaik sebenarnya dalam penyembuhan klien adalah di dalam lingkungan keluarga dengan begitu klien bisa berinteraksi dan melakukan aktualisasi diri secara normal. Disamping itu sebagian dari pasien juga kembali dirawat, bukan karena penyakitnya kambuh lagi, namun karena ia lebih suka tinggal di Rumah Sakit ketimbang di lingkungannya. Hal ini dimunkinkan karena (Anugrah, 2018).

\section{SIMPULAN}

Terdapat hubungan pengetahuan terkait perawatan pasien jiwa di rumah dengan kekambuhan, didapatkan nilai $p=0,003$ berarti $p<$ a $(0,05)$, maka Ho ditolak dan Ha diterima ini menunjukkan adanya hubungan antara pengetahuan keluarga tentang perawatan pasien di rumah dengan kekambuhan. Terdapat Hubungan Sikap Keluarga terkait perawatan pasien jiwa di rumah dengan kekambuhan, didapatkan nilai $p=0,002$ berarti $p<a(0,05)$, maka Ho ditolak dan $\mathrm{Ha}$ diterima ini menunjukkan adanya hubungan antara Sikap Keluarga terkait perawatan pasien jiwa di rumah dengan kekambuhan di UPTD Pukesmas Batanghari Kabupaten Lampung Timur.

\section{SARAN}

Perlu dipertimbangkan untuk meningkatkan program-program penyuluhan berupa edukasi keluarga sebagai primary support group dan pengurangan expressed emotion dalam lingkungan keluarga untuk mencegah kekambuhan yang menyebabkan tinggi frekuensi rawat inap pasien skizofrenia.

\section{DAFTAR PUSTAKA}

Akbar, M. (2008). Skizofrenia psikosa (sakit jiwa). Jakarta: Balai.

Andri, A.(2008). Kongres Nasional Skizofrenia V Closing the Treatment Gap for Schizophrenia, (online), (http://www.kabarindonesia/berita, diakses 23 Februari 2011).

Anugrah, A. K. (2018). Hubungan Antara Dukungan Keluarga Dan Tingkat Stres Pada Lansia Di Balai PSTW Unit Budhi Luhur Kasongan Bantul Yogyakarta.

Ashturkar, M. D., \& Dixit, J. V. (2013). Selected Epidemiological Aspects of Schizophrenia: A Cross Sectional Study At Terityary Care Hospital In Maharashtra. Journal of Community Medicine, 65, 69

Dinas Kesehatan Kabupaten Lampung Timur. (2016). Profil Kesehatan Kabupaten Lampung Timur

Direja, A. H. S. (2019). Hubungan pengetahuan dan peran keluarga dengan kekambuhan pasien skizofrenia di poliklinik rskj soeprapto provinsi bengkulu. CHMK Nursing Scientific Journal, 3(2), 80-88.

Elpinar, E., Indriastuti, D., \& Susanti, R. W. (2019). Hubungan Dukungan Emosional Keluarga dan Kebutuhan Spiritual dengan Tingkat Stres

\section{Slamet Rahayu', Teguh Pribadi ${ }^{2 *}$, Yansuri ${ }^{3}$}

'UPTD Puskesmas Batanghari Kabupaten Lampung Timur ${ }^{2}$ Program Studi llmu Keperawatan Universitas Malahayati

${ }^{3}$ Rumah Sakit Jiwa Daerah Provinsi Lampung

Korespondensi Penulis: Teguh Pribadi. *Email: teguh@malahayati.ac.id 
Hubungan kekambuhan pada pasien skizofrenia dengan pengetahuan dan sikap keluarga dalam merawat pasien

Narapidana di Lembaga Pemasyarakatan Perempuan Kelas III Kendari. Jurnal Keperawatan, 3(02), 1-9.

Gusdiansyah, E. (2018). Hubungan dukungan dan beban keluarga dengan tingkatan skizofrenia. Jurnal Kesehatan Lentera'Aisyiyah, 1(1).

Hastuti, R. Y., \& Varlinda, A. K. (2017). Hubungan Pengetahuan Keluarga Tentang Personal Hygiene Dengan Kemampuan Keluarga Merawat Anggota Keluarga Yang Mengalami Gangguan Jiwa. Profesi (Profesional Islam): Media Publikasi Penelitian, 14(2), 70-76.

Hawari, D. (2014). Pendekatan Holistik pada Gangguan Jiwa Skizofrenia, edisi ke3. Jakarta: Balai Penerbit Fakultas Kedokteran Universitas Indonesia. HIm, 19-20.

Kementerian Kesehatan Republik Indonesia. (2013). Riset Kesehatan Dasar 2013. Jakarta: Kementerian Kesehatan RI. Diakses dari: http://kesga.kemkes.go.id/images/pedoman/Dat a\%20Riskesdas\%202013.pdf

Kusumaningtyas, R., \& Widodo, A. (2017). Pengaruh Pendidikan Kesehatan Jiwa Keluarga Terhadap Pengetahuan Dan Sikap Pencegahan Kekambuhan Gangguan Jiwa Di Desa Makamhaji Kecamatan Kartasura Kabupaten Sukoharjo (Doctoral dissertation, Universitas Muhammadiyah Surakarta).
Notoatmodjo, S.(2012).Promosi kesehatan teori dan aplikasi. Jakarta : PT. Rineka Cipta

Rahakbauw, N. (2018). Dukungan keluarga terhadap kelangsungan hidup ODHA (Orang Dengan HIVIAIDS).

Riyanto, A. (2011). "Buku Ajar Metodologi Penelitian." Jakarta: EGC

Tabrani, P. (2014). Proses Kreasi-Gambar AnakProses Belajar. Jakarta: Erlangga

Townsend, M. C. (2011). Diagnosa keperawatan pada keperawatan Psikiatri.

Wiharjo, G.F. (2014). Hubungan Persepsi dengan Sikap Masyarakat Terhadap Penderita Skizofrenia di Surakarta (Doctoral dissertation, Universitas Muhammadiyah Surakarta).

World Health Oraganization.(2013). Mental health action plan 2013 - 2020. Diakses dari https://www.who.int/mental_health/publications/ action_plan/en/

\section{Slamet Rahayu', Teguh Pribadi ${ }^{2 *}$, Yansuri ${ }^{3}$}

'UPTD Puskesmas Batanghari Kabupaten Lampung Timur ${ }^{2}$ Program Studi llmu Keperawatan Universitas Malahayati ${ }^{3}$ Rumah Sakit jiwa Daerah Provinsi Lampung

Korespondensi Penulis: Teguh Pribadi. *Email: teguh@malahayati.ac.id 